\title{
Research on the Cultivation of College Students' Innovation and Entrepreneurship Based on Technological Innovation Platform
}

\author{
Kunquan Shi \\ College of Information Engineering, Guangzhou Panyu Polytechnic College, Guangzhou 511483, \\ China \\ 529856330@qq.com
}

\begin{abstract}
Keywords: Science and Technology Innovation Platform; College Students; Innovation and Entrepreneurship; Ability Development
\end{abstract}

\begin{abstract}
China must first become a big country with talents to become a big country with innovation. The primary task must be to become a big country with education and a strong country with education. Higher education is charged with the sacred mission of practicing "mass entrepreneurship and innovation". How to guide and promote college students to achieve "mass entrepreneurship and innovation" is an issue that must be considered in the reform of contemporary higher education. As an important base and place for university students' innovation and entrepreneurial ability training, University Science Park plays an important role in cultivating innovative and entrepreneurial talents. At present, undergraduates in our country still have problems in their ability to start a business, have a weak atmosphere of innovation, and have a low rate of transformation of scientific and technological achievements. The university science and technology park, as a link between universities and society and markets, has become an important platform for university student to carry out innovation and entrepreneurship with its superior innovation environment and rich entrepreneurial resources. Therefore, it is of great significance to build and play a role in the platform of university science parks for the cultivation of college students' innovation and entrepreneurship. This article describes how to cultivate students' innovation and entrepreneurship ability relying on the platform of science and technology innovation.
\end{abstract}

\section{Introduction}

With the advent of the Internet age, it constantly calls for high-quality creative talents. Along with the rapid growth of the pace of economic and social integration in the world, the world's competition has also intensified, and innovation and entrepreneurship have been the main driving forces for the nation's overall development in the $21 \mathrm{st}$ century, the "pushing device" for the development of modern technology, either. Innovation and entrepreneurship, from the perspective of university students' training, is a development strategy that is in line with the general direction of macroeconomics. It is the mission and responsibility that universities now urgently need to complete. In our country, each historical stage in the past has not been so urgent to promote innovation and entrepreneurship. Innovation and entrepreneurship education for college graduates is in line with the needs of modern society, and is a powerful impetus for the nation's economic development and economic transformation. At the same time, it is a top priority for higher education reform. Strengthen the Internet age and improve college students' ability to innovate and innovate. We have put forward some safeguard measures and put forward some general directions for deepening reforms. College innovation and entrepreneurship education as a new type of education to promote social and economic development, its development situation is an inevitable trend of social development, but for now, China's innovation and entrepreneurship education is still in its infancy, its theoretical research is relatively few and lacks corresponding practical activities, through the search and analysis of the existence of these problems, this paper aims to cultivate the basic principles of college students and guide them in various aspects. 


\section{The Problems Existing in College Students' Innovation and Entrepreneurship in China}

The enthusiasm for innovation and entrepreneurship is high, but the actual ability needs to be improved. With the deepening of the reform of quality education in our country, many colleges and universities take the construction of research-oriented universities and the cultivation of innovative and entrepreneurial talents as the main direction of running a school. The university students' sense of innovation and passion for entrepreneurship have gradually increased. Each year, college graduates embark on the path of self-employment. The number of students is increasing, but the proportion of undergraduates who actually participate in entrepreneurship and can successfully embark on self-employment is very low.

The conversion rate of college students' innovative and entrepreneurial scientific and technological achievements is relatively low. Although college students have certain unique advantages in the process of innovation and entrepreneurship, such as strong entrepreneurial spirit and certain professional knowledge, due to the lack of social practical experience, lack of venture capital and other issues, product design research and development can't be carried out smoothly, the conversion rate of scientific and technological achievements. low.

Innovation and entrepreneurship education is insufficient. In primary school, the school advocated the development of our intellectual, artistic, and art work. In fact, we actually implemented the hero teaching model based on the results of cultural classes. Although some colleges and universities have realized the importance of innovation and entrepreneurship, they lack the correct guidance of national policies. Less colleges and universities took the wrong road, blindly carried out some educational reforms according to their own thinking, and a large number of non-professional staff and workers were intermingled. They carried out informal and imperfect innovation and entrepreneurship education for contemporary college students, which leads to contemporary college students only start to explore and learn only when they actually enter the workplace. However, some innovative and entrepreneurial professional teaching staff also insist on keeping some old teaching thinking to guide students onto some incorrect entrepreneurial roads and cannot fully reform education and teaching methods. More college students have a serious lack of social practice experience. When they step into society, they are like hitherto flies. They are hitting the wall everywhere. This is inextricably linked with the national plus policies and the state's small investment in innovation and entrepreneurship education. Relative to other developed countries, our understanding and start of this type of education are too late, so the form is still harsh.

The social and cultural atmosphere of college students' innovation and entrepreneurship is weak. Affected by the concept of traditional education and education, the social and cultural atmosphere that currently supports undergraduates' innovation and entrepreneurship is not yet strong, lacking recognition and policy support from society, families, and related departments.

\section{Building a Platform for Cultivating College Students' Science and Technology Innovation Ability Based on Subject Advantage Resources}

Integrate Advantageous Resources of Disciplines and Construct a Practice Base for University Students' Scientific and Technological Innovation Ability. At present, in China's universities, graduate students can have frequent contact with the mentor, subtly accept the influence and influence of the mentor, and the laboratory can also be open to them throughout the day. The undergraduates have almost no contact with teachers during their spare time, and they are hardly allowed into the laboratories. Therefore, we need to integrate many well-known professors, scientists and academic leaders from various departments to encourage them to guide university students to complete scientific and technological innovation activities and practices. This also requires students to provide a research site or base that can be carried out at any time to meet the research needs of students who have a strong interest in professional research and technological innovation. Colleges and universities can consider relying on high-quality laboratory resources to build a cultivation base for university students' scientific and technological innovation capabilities, equipped with necessary experimental instruments and equipment, and arrange special personnel 
guidance, open to students all-weather, and provide a good practice base for students' scientific and technological innovation ability training.

Actively build a four-in-one student science and technology competition system. After the college students have practiced in the scientific and technological innovation ability cultivation base, their research achievements or experience must also have a platform for exchange and comparison, so as to further promote the cultivation of students' scientific and technological innovation capabilities. Student science and technology competition is a good carrier to achieve this goal. On the one hand, students can demonstrate scientific research results through competitions, encourage students of all levels to participate in scientific and technological activities. On the other hand, students can also carry out science and technology achievements through competitions. Through comparison, the gap between the similar universities and similar works can be identified and the scientific research level of students can be further improved.

Specifically, colleges and universities should build a science and technology competition system consisting of national competitions, provincial competitions, school-level contests, and college-level competitions, that is, the national challenge cup competition, mathematical modeling competition, electronic design competition and other national competitions as the leading. Take an active part in the match at the provincial level, and at the same time to carry out the campus pageant all competitions, as competition for Kentucky university, competition for the tower at the provincial level, national competition for the top four tower integrated disciplines competition system, so as to achieve standardization, specialization and refinement of student technology competition.

\section{Ways to Cultivate College Students' Creative and Innovative Ability}

To carry out innovation and entrepreneurship education for college students. To carry out innovation and entrepreneurship education for college students is an important measure for cultivating compound talents. At the same time, innovation and entrepreneurship education as a new model of educational development is conducive to the improvement of the comprehensive quality of college students and is conducive to accelerating the pace of scientific and technological progress in China. Strengthening the innovation and entrepreneurship education for college students can be discussed in several aspects.

a. The establishment of innovation and entrepreneurship theory courses is an important part of cultivating college students' innovative and entrepreneurial abilities, focusing on market orientation, inspiring college students to correctly identify and grasp business opportunities, and formulating their own actual conditions making the entrepreneurial plan;

b. Actively explore the entrepreneurial practice and project practice training mode focusing on entrepreneurs;

c. Conduct one-on-one, peer-to-peer entrepreneurial project coaching training based on the professional curriculum of college students and their own characteristics, and strengthen innovation awareness and entrepreneurship. Improvement of skills.

The construction of a science and technology innovation and entrepreneurship practice base is a strong support. The innovation and entrepreneurship practice base not only builds a bridge for students to communicate with society and enterprises, but also paves the way for college students to embark on society in the future. In particular, many high-tech projects in the practice base, through the acceptance of university students involved in business management, technology research and development of the entire process, not only can the company reserve the necessary talent, but also can make college students get real exercise, accumulate work experience, for better Support innovation and entrepreneurship.

Increase support for college students' innovation and venture capital. The insufficiency of innovation and venture capital has become the bottleneck of the current constraints on the success of college students on the road to entrepreneurship. Many college students even have good entrepreneurial projects on hand, but they are not able to implement it because of the lack of initial venture capital. The university science park high-tech project incubation base can provide strong support for college students' innovation and entrepreneurship through the development of 
entrepreneurial skill competitions, the establishment of innovative venture capital funds, and the joint implementation of innovation and entrepreneurship high-tech project achievements. At the same time, increase the support of local governments, high-tech enterprises established by college graduates from the project admission, incubation, taxation and other aspects to give policy support to reduce the college graduates face various initial pressures.

\section{Measures to Promote College Students' Innovation and Entrepreneurial Ability}

Deepen understanding and establish a long-term mechanism for fostering college students' abilities in innovation and entrepreneurship. The high-tech projects of the University Science Park meet the needs of market development. With high technological content and broad prospects for development, colleges and universities are taking more social responsibilities and accelerating the combination of knowledge and technology innovation and social innovation systems, which play an important role in cultivating innovative entrepreneurial talents. High-tech projects of university science parks, while being market-oriented to create more economic benefits for the society, also bear certain social responsibilities and are an important part of the socialist higher education system with Chinese characteristics. It is imperative to establish a long-term mechanism for fostering college students' innovative and entrepreneurial ability. Through the establishment of a long-term mechanism, we will encourage and encourage more outstanding students to go to university high-tech projects in science parks or high-tech enterprises to develop internships, foster innovation awareness, create thinking and entrepreneurial spirit, mobilize them to follow the path of entrepreneurial innovation, and accelerate economic development and progress in science and technology in China.

Optimize the innovative educational curriculum system and introduce the innovative driving model of the scientific and technological innovation platform into the curriculum system. On the basis of the existing curriculum system, the teaching content of engineering practice related to the science and technology innovation platform project will be increased to provide students with opportunities for cognitive engineering practice, increase the proportion of innovative teaching content, and improve students' independent innovation ability and awareness. Build a platform for all-round innovative practice support and promote the development of students' innovative practical activities. In order to solve the problem of insufficient practical investment in the conventional model, an all-round scientific and technological innovation practice platform combining "guidance, motivation, and environment" is established to establish a good engineering practice orientation, improve the incentive mechanism, optimize the engineering practice environment, and subjectively inculcate practice concepts. It stimulates practical enthusiasm, objectively provides all-weather engineering practice conditions, promotes students' independent practice, and maximizes students' comprehensive innovation capabilities. Implementing through-innovation and practice activities combining inside and outside classes to build a three-dimensional integrated practice system. In order to solve the problems of rigid curriculum structure and limited knowledge of scientific knowledge in conventional teaching, through the reform of the traditional curriculum system, the content of engineering practice has been increased to form a through-type curriculum system, and a three-layer practice model of basic practice, comprehensive practice and innovation practice has been constructed. In the end, students' knowledge is gradually changed from theory to practice to engineering application. The knowledge system of "wide-disciplinary specialty, deep-engineering frontier, and thick-matrix theoretical basis" is established.

\section{Summary}

The cultivation of college students' science and technology innovation ability is not only related to the development of individual students, but also related to the quality of college students training, whether it can cultivate a large number of scientific and technological innovation talents with higher comprehensive quality, also related to China's overall national strength and Increased international 
competitiveness. It is an important task for colleges and universities to cultivate innovative and entrepreneurial ability of college students. The academic orientation, scientific research ability, and faculty team and other advantages of university science and technology innovation platform are the fertile ground for cultivating college students' ability for innovation and entrepreneurship. Starting from the actual situation of university science and technology innovation platform, we will build a new mode of innovation and entrepreneurship training in terms of optimizing curriculum systems, building new types of teachers, and cooperation between schools and enterprises.

\section{Acknowledgements}

This research was financially supported by Education teaching reform project of guangzhou university (Grant NO.2017E02), Guangzhou university innovation and entrepreneurship education project (Grant NO.201709T07)

\section{Reference}

[1] Shi Q L. On Target Localization and Contents of Innovation and Entrepreneurship Education in Colleges and Universities[J]. Journal of Changzhou Vocational College of Information Technology, 2012.

[2] Adhikari, B., Bliese, A., Davis, E., \& Halawi, L. (2014). Promoting innovation and high-tech entrepreneurship in historically black colleges and universities. Issues in Information Systems, 15(1), 303-311.

[3] Zhao Z, Guo Y, Zhang W, et al. Analysis of innovation and entrepreneurship education in colleges and universities in Qinghai Province[J]. Journal of Qinghai University, 2014.

[4] Weng F, Ke L, Ding M, et al. On Innovation and Entrepreneurship Education in Colleges and Universities of Traditional Chinese Medicine[J]. Journal of College Advisor, 2015.

[5] Huang X H. On the Practical Teaching Mechanism of Innovation and Entrepreneurship Education in Colleges and Universities[J]. Heilongjiang Researches on Higher Education, 2015.

[6] Jiang $\mathrm{H}$, Yin $\mathrm{H}, \mathrm{Xu} \mathrm{X}$. Research on the Mode of Cultivating Talents of Innovation and Entrepreneurship in Colleges and Universities[J]. Journal of National Academy of Education Administration, 2015.

[7] Wang L H, Xiao Y J. Exploration and Research on the Mode of Innovation and Entrepreneurship Education in Colleges and Universities[J]. Education Teaching Forum, 2016.

[8] Cheng L, Ren H, Yao H, et al. The Construction of Innovation and Entrepreneurship Education System in Colleges and Universities[J]. Farm Products Processing, 2016.

[9] Tian L H, Sun Y X, You Y. Construction of Training Platform for Innovation and Entrepreneurship in Colleges and Universities Based on MOOC[J]. Value Engineering, 2017.

[10] Liao W Z. Research on innovation and entrepreneurship education in colleges and universities[J]. Journal of Hunan Post \& Telecommunication College, 2017.

[11] Liang K. Research on the Development Mode of Innovation and Entrepreneurship Education in Colleges and Universities under the Background of Supply Side Reform[J]. Science Education Article Collects, 2017.

[12] Chang-Hai Y U. Reflections on Deepening the Reform of Innovation and Entrepreneurship Education in Colleges and Universities[J]. Education Teaching Forum, 2017.

[13] Song X J. Construction of Ecological System of Innovation and Entrepreneurship Education in Colleges and Universities[J]. Value Engineering, 2016.

[14] Ma R. Problems and Countermeasures on Personnel Training of Innovation Entrepreneurship in Colleges and Universities[C]// International Conference on Education, Management and Computing Technology. 2017. 